\title{
PRELIMINARY RESULTS AND CONCLUSIONS FROM THE EXPERIMENTAL MONITORING OF THERMAL REGIME OF RAILWAY TRACK STRUCTURE
}

\author{
L. IŽVOLT, P. DOBEŠ \& M. PITOŇÁK \\ Department of Railway Engineering and Track Management, \\ Faculty of Civil Engineering, University of Žilina, Slovakia.
}

\begin{abstract}
The article describes the preliminary results and conclusions of experimental monitoring of the thermal regime of railway track structure performed on the experimental stands (railway track models in 1:1). The purpose of this study was to optimize the structural thickness of the protective layer in the subgrade structure. The first part of the study describes the experimental stand design and methodology for monitoring the heat and humidity variations in the railway track structure. The following parts describe the results of verification of the thermal characteristics of the material incorporated into the model of the railway track and of its subgrade.
\end{abstract}

Keywords: climatic factors, experimental monitoring of thermal regime, railway track, subgrade dimensioning.

\section{INTRODUCTION}

The quality and safety of railway tracks are clearly dependent not only on the technical level and state of train sets but also on the state and quality of the railway superstructure and substructure. They compose one technical-physical unit, affecting the required operational capability and railway track safety. Due to this, the Department of Railway Engineering and Track Management (DRETM) of the University of Žilina has been paying long-term attention to the problem of railway substructure reliability under the influence of various factors, with specific focus on climatic factors $[1,2]$. The course of winter periods, particularly over the past 20-30 years, shows different trends than in the past. As a result, there is a necessity to update the input design parameters of subgrade structure dimensioning, or possibly to amend the dimensioning methodology stated in [3] as it reflects the research results from the 1960s.

In the Slovak Republic, as well as in neighbouring countries, the weather characteristics of the winter period considerably influence the dimensions of the subgrade structure. Because of this, it is necessary to identify and include the influence of changing climatic conditions on the railway substructure into the design methodology of subgrade structure dimensioning for non-traffic loads (influence of climatic factors). Concerning foreign research, in the past, this problem was analysed in Germany, Norway, Japan and Canada. At present, the most commonly used research output is from UIC ORE research, which is carried out under the auspices of Trondheim University. This research took into account the climatic conditions of the 1960s and the 1970s. The importance of studying the problem of the thermal regime of railway track structure (subgrade) can be underlined by the fact that new construction

This paper is part of the proceedings of the 15th International Conference on Railway

Engineering Design and Operation (COMPRAIL)

www.witconferences.com 
materials and structural elements are applied within the rail track modernisation, and as it was stressed before, the climatic conditions for present and future railway track operation have been changed.

\section{EXPERIMENTAL MONITORING OF THERMAL REGIME AND CHANGES IN HUMIDITY OF THE RAILWAY TRACK STRUCTURE}

The problem of monitoring the thermal regime of railway track structure has been solved at the DRETM, Faculty of Civil Engineering of the University of Žilina (FCE, ŽU - UNIZA) for at least two decades. At present, the research also focuses on verification of thermal conductivity coefficients, $\lambda$, and variations in humidity of various materials applied in the subgrade structure and on monitoring the influence of winter period courses (the number of frost periods and size of the frost index) and the average annual temperature on the depth of subgrade freezing. This study is carried out using experimental stands of railway track models and software support for mathematical modelling of the thermal regime and variations in humidity of railway track structure. The following section of the article will briefly describe the experimental basis that DRETM uses for monitoring the thermal regime and variations in humidity at the experimental stands with railway track models.

\subsection{Experimental stand DRETM I}

The experimental measurements at the railway track model in the scale 1:1 were started as early as in 2003. The structure of the railway track model, the so-called experimental stand DRETM I (see Fig. 1), was built as a track section run on terrain level. The railway superstructure consists of rail skeleton and ballast bed (BB) fraction 31.5/63 mm of total thickness $500 \mathrm{~mm}$. The railway substructure composes the subgrade with in-built MACRIT GTV/50 geocomposite, where the protective layer of subgrade surface is formed by $450 \mathrm{~mm}$ thick layer of crushed aggregate fraction $0 / 31.5 \mathrm{~mm}$ and its soil material is sandy clay. The thickness of the protective layer was dimensioned in compliance with the then in force regulation [4], where the design value of air frost index for Žilina was $I_{F}=550^{\circ} \mathrm{C}$.day. To monitor the temperatures in the individual structural layers of this experimental stand, we installed 11 resistance thermometers, Pt100, whose arrangement can be observed in Fig. 1. An important piece of input data in the process of monitoring the effects of non-traffic loads is the air temperature that is being measured $2.00 \mathrm{~m}$ above the level of the surrounding terrain and serves as a determination of the frost index value, $I_{F}$.

We are aware of the fact that snow decreases the effects of frost on a subgrade and acts as an insulation layer. To monitor its effects, we removed the snow cover completely during winter or, conversely, the snow cover of maximum height approx. $0.12 \mathrm{~m}$, which takes into account the real operational conditions, is kept.

At this experimental stand during each winter period, the following characteristics were monitored and determined:

- mean daily temperature, $\theta_{s}$,

- minimal temperature in the individual structural layers of the stand, $\theta_{\min }$,

- depth of structural freezing in the given period, $D_{F}$,

- air frost index, $I_{F}$,

- mean daily surface temperature, $\theta_{s s}$,

- frost index at the track bed surface, $I_{F S}$. 


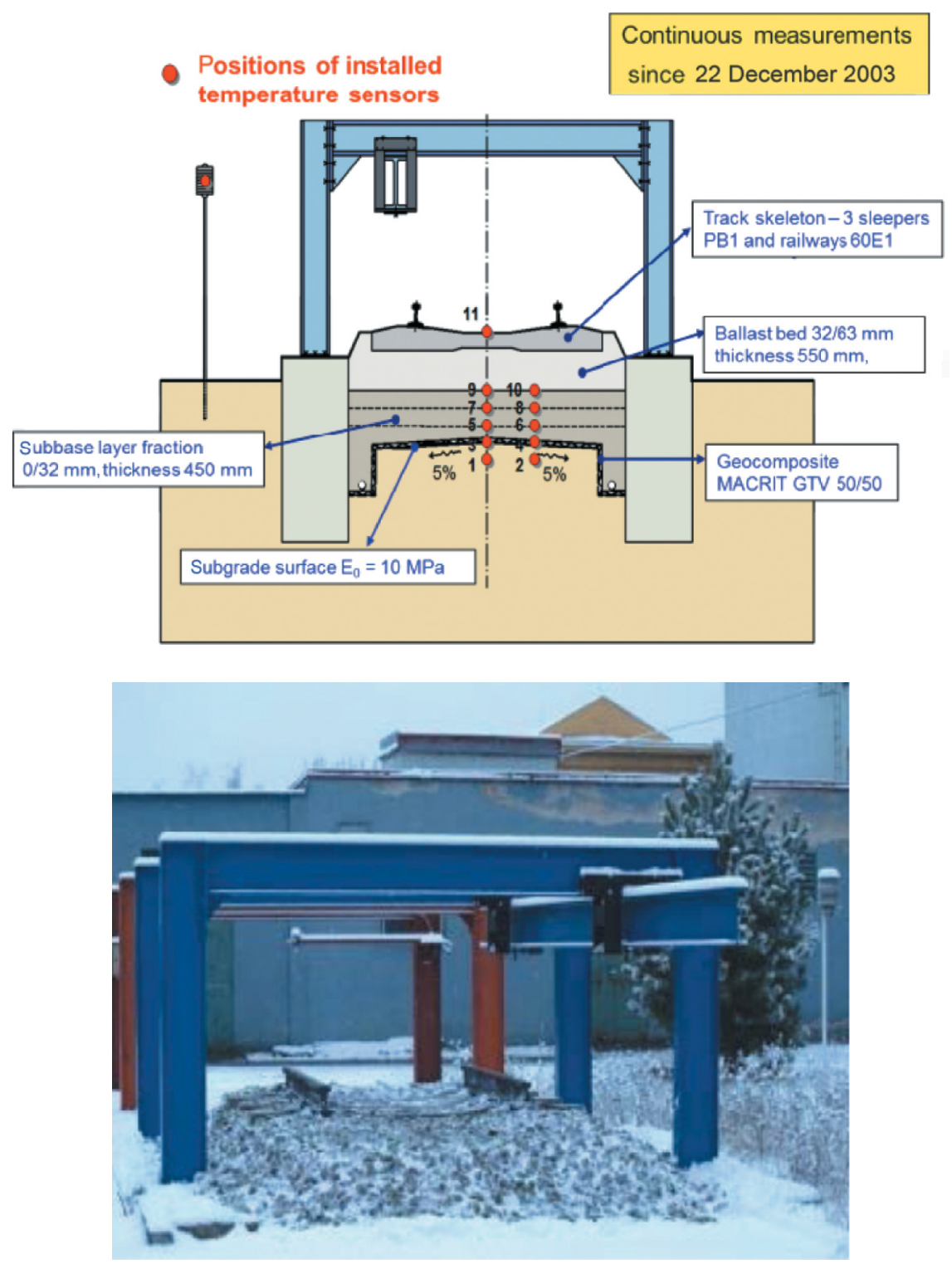

Figure 1: Experimental stand DRETM I.

This experimental stand, besides being used for monitoring the development and course of the subgrade thermal regime during individual winter periods, also served for monitoring the variations in deformation resistance. This was facilitated by a steel frame with a mobile beam and set for measuring the static and dynamic modulus of deformation.

The courses of 12 winter periods were recorded from 2003 to 2015. Their monitored characteristics are stated in Table 1 . The winter period, the above-mentioned parameters were stated for, is limited by the first and last frost period $\left(\theta_{s} \leq-0.1^{\circ} \mathrm{C}\right)$, while the frost period must last for at least 4 days. 
Table 1: Overview of monitored climatic quantities at the experimental stand DRETM I $[5,6]$.

\begin{tabular}{|c|c|c|c|c|c|c|}
\hline $\begin{array}{l}\text { Winter } \\
\text { period }\end{array}$ & $\begin{array}{c}\text { Temperature, } \\
\theta_{s, \max } \\
\left({ }^{\circ} \mathrm{C}\right)\end{array}$ & $\begin{array}{c}\text { Temperature, } \\
\theta_{s, \min } \\
\left({ }^{\circ} \mathrm{C}\right)\end{array}$ & $\begin{array}{c}\text { Frost } \\
\text { index, } \\
I_{F} \\
\left({ }^{\circ} \text { C.day) }\right.\end{array}$ & $\begin{array}{c}\text { Surface } \\
\text { frost } \\
\text { index, } \\
I_{F S} \\
\left({ }^{\circ} \text { C.day) }\right.\end{array}$ & $\begin{array}{c}\text { Depth of } \\
\text { freezing, } \\
D_{F} \\
\text { (m) }\end{array}$ & $\begin{array}{c}I_{F} \\
\text { for } \\
D_{F, \max } \\
\left({ }^{\circ} \text { C.day) }\right.\end{array}$ \\
\hline $2003 / 2004^{a}$ & 13.19 & -12.31 & -168 & -58 & 0.46 & -29 \\
\hline $2004 / 2005$ & 7.97 & -13.37 & -228 & -143 & 0.70 & -165 \\
\hline $2005 / 2006^{a}$ & 5.71 & -16.68 & -388 & -248 & 0.82 & -334 \\
\hline $2006 / 2007$ & 13.02 & -5.26 & -16 & -14 & 0.33 & -9 \\
\hline $2007 / 2008$ & 8.55 & -8.15 & -96 & -91 & 0.48 & -20 \\
\hline $2008 / 2009$ & 11.13 & -11.78 & -150 & -130 & 0.58 & -145 \\
\hline $2009 / 2010$ & 10.40 & -13.27 & -204 & -149 & 0.60 & -145 \\
\hline $2010 / 2011$ & 5.67 & -12.27 & -215 & -145 & 0.61 & -215 \\
\hline $2011 / 2012$ & 4.93 & -15.20 & -238 & -207 & 0.98 & -184 \\
\hline $2012 / 2013^{a}$ & 10.68 & -11.45 & -162 & -54 & 0.44 & -107 \\
\hline $2013 / 2014$ & 11.21 & -10.50 & -27 & -33 & 0.46 & -23 \\
\hline $2014 / 2015$ & 9.14 & -8.95 & -40 & -20 & 0.34 & -15 \\
\hline
\end{tabular}

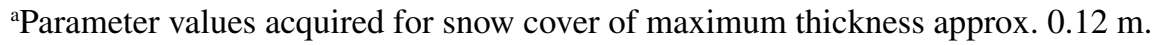

Table 1 clearly shows that the coldest winter period in the last 12 years was the winter period of 2005/2006, when the air frost index reached the value $I_{F}=-388^{\circ} \mathrm{C}$.day, although the subgrade freezing depth in this winter period was not the lowest, as it reached the value $D_{F}=0.82 \mathrm{~m}$ (freezing of subgrade surface did not occur).

From the point of view of subgrade freezing, the winter of 2011/2012 can be considered the most unfavourable winter period, when the depth of structural freezing reached the value $0.98 \mathrm{~m}$ for a maximum frost index of, $I_{F}$, only $-238^{\circ} \mathrm{C}$.day. This winter period is the only one when the zero isotherm penetrated into the subgrade below the subgrade surface level, which is located at the depth of $0.95 \mathrm{~m}$ below the BB surface. The higher value of the depth of subgrade freezing at the lower frost index compared to the winter period 2005/2006 is a consequence of snow removal from the BB surface during the entire winter period.

The most favourable winter period, not only from the point of view of subgrade freezing but also due to the reached air frost index $I_{F}$, was the winter period of 2006/2007, when the subgrade freezing depth reached the value of only $0.33 \mathrm{~m}$ and the maximum air frost index $-16^{\circ} \mathrm{C}$.day, which means that there was no freezing of the entire BB structural thickness.

For individual dimensioning of subgrade structure (the thickness of protective layer of subgrade surface), the repeatability of winter periods is important. If the winter period of $2003 / 2004$ is compared to the winter period of 2012/2013, or the winter period of 2009/2010 to the winter period of $2010 / 2011$, it can be ascertained that the differences in frost indices (on the BB surface, $I_{F S}$ ) and depths of subgrade freezing, $D_{F}$, are only minimal. Table 1 also 
clearly shows that the air frost index, $I_{F}$, is not the only parameter affecting the depth of subgrade freezing, $D_{F}$. The depth of subgrade freezing, $D_{F}$, is, besides the occurrence of snow cover on the rail track surface, also influenced by the average annual air temperature, $\theta_{m}$ (the amount of heat accumulated in the subgrade), and - certainly - by the humidity of subgrade materials before the first frost period.

\subsection{Experimental stand DRETM II}

In order to consider the results from the Experimental stand DRETM I and the efforts to load the subgrade structure by the maximum effects of frost, an experimental stand DRETM II was designed and constructed in 2012. The concept and design of the experimental stand was based on the long-term experience gained from the experimental measurements of the subgrade thermal regime at the experimental stand DRETM I. As at the time of construction of the experimental stand DRETM II the software for mathematical modelling of the subgrade thermal regime was available, besides higher number of thermal sensors, humidity sensors were also embedded to acquire one of the input parameters for mathematical modelling of the thermal regime using SoilVision software (see [7]).

The experimental stand DRETM II represents the railway track model run on the embankment in the scale 1:1 - Figs. 2 and 3. The superstructure of this model consists of the track skeleton and BB fraction 31.5/63 mm of overall thickness $500 \mathrm{~mm}$. From the structural point of view, this experimental stand is divided into two structural parts. The first part (half) of the experimental stand (measuring profile 1) is the entire earthwork at the height of approximately $1.00 \mathrm{~m}$ built of crushed aggregate fraction $0 / 63 \mathrm{~mm}$ (reclaimed rail ballast) and its subgrade is formed by clay with an addition of river gravel (identified by the geotechnical investigation). The second part (half) of the experimental stand (measuring profile 2) consists of a protective (subbase) layer of crushed aggregate fraction $0 / 31.5 \mathrm{~mm}$ at the thickness of $450 \mathrm{~mm}$, placed on the subgrade surface. The earthwork, $550 \mathrm{~mm}$ high, is built of crushed aggregate, a fraction $0 / 63 \mathrm{~mm}$ and foundation soil also of clay with an addition of river gravel. The thickness of the protective layer was equal to the experimental stand DRETM I dimensioned in accordance with the regulation [4], to enable the comparison of structures

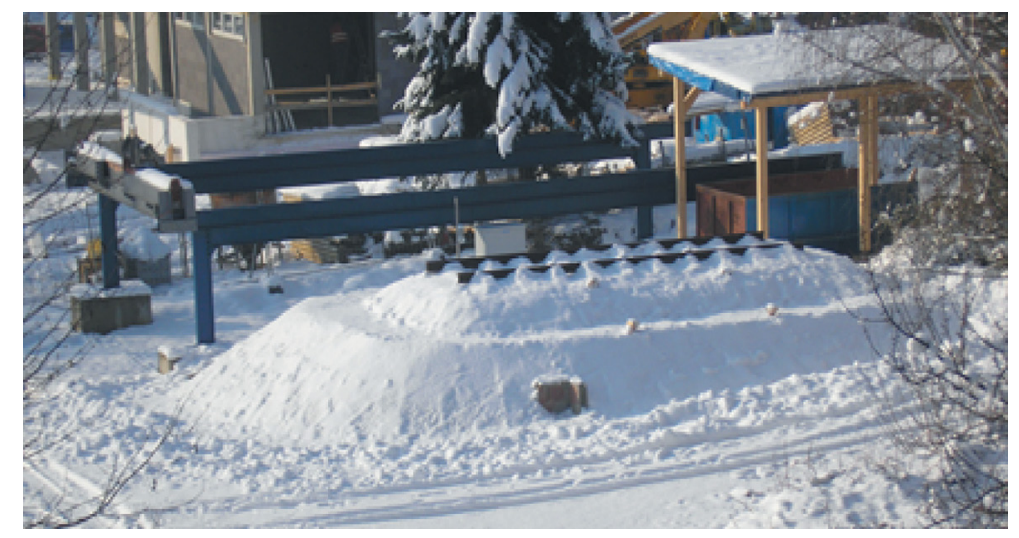

Figure 2: In the foreground: snow-covered experimental stand DRETM II on the Žilina university campus. 


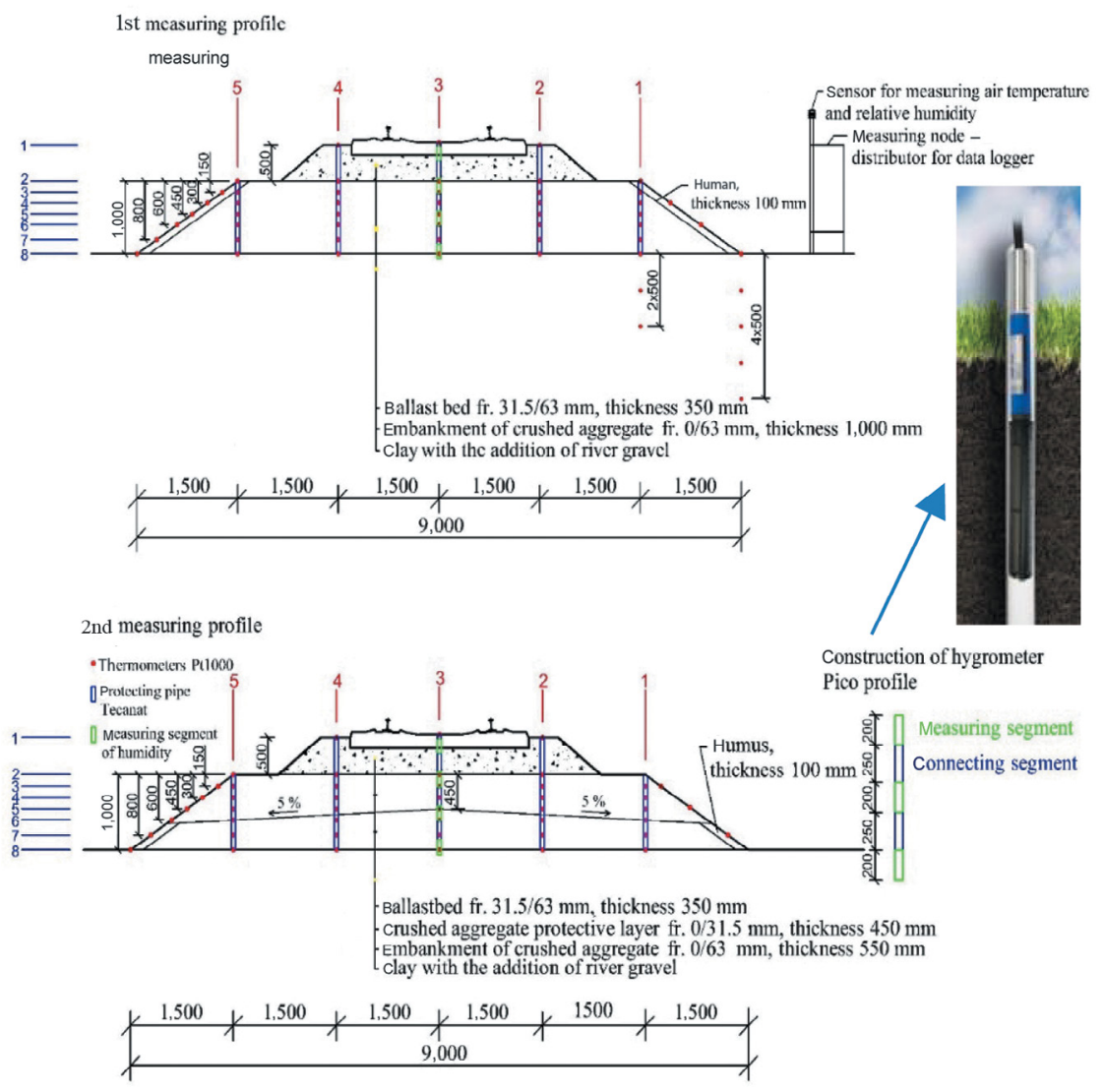

Figure 3: Cross sections of the experimental stand DRETM II.

from the point of view of thermal regime and the position of zero isotherm. The slope treatment was finished with topsoil application at the thickness of $0.10 \mathrm{~m}$ and the slopes were grassed over.

To monitor the thermal regime in the experimental stand DRETM II, 100 resistive temperature sensors, type Pt1000 (measuring range from $-50^{\circ} \mathrm{C}$ to $+400^{\circ} \mathrm{C}$ ), were embedded. The temperature sensors were placed in each measuring profile on eight horizontal levels, in a mutual distance of $150 \mathrm{~mm}$ (the distance of the last two levels is $200 \mathrm{~mm}$ ) and in five rows, while some thermal sensors were also placed on the surface of both embankment slopes, or below the level of the original terrain.

Besides the thermal sensors, the experimental stand also featured protective insulated pipes for humidity sensors of the type PICO-T3P (Fig. 3), enabling non-destructive humidity measurement in the range from $-15^{\circ} \mathrm{C}$ to $+50^{\circ} \mathrm{C}$ with a precision of $\pm 2 \%$ [8]. To prevent damage to the probe tube in contact with sharp material, we placed the probe tube into a special protective pipe TECANAT at a diameter of $40 \mathrm{~mm}$. The placement of the TECANAT pipes of humidity sensors is similar to the thermal sensors, thus in five rows, while the thermometers were placed outside the pipes. The structure of the experimental stand included 11 protective pipes ( 5 in each measuring profile and 1 pipe placed in the foot of the embankment to measure the 
humidity of the embankment subbase). The arrangement and position of individual thermal and humidity sensors in the experimental stand DRETM II is shown in Fig. 3.

In the vicinity of the experimental stand the sensor Comet T3419 was installed, which served for acquiring the data about the air temperature and humidity in the height of $2.00 \mathrm{~m}$ above the terrain. The air temperatures can be recorded in the range of $-30^{\circ} \mathrm{C}$ to $+105^{\circ} \mathrm{C}$ with a precision of $\pm 0.4^{\circ} \mathrm{C}$ and the air humidity in the range of $0-100 \%$, with a precision of $\pm 2.5 \%$.

As experimental stand DRETM II serves the same purpose as the previous structure (experimental stand DRETM I), identical parameters, stated in paper, are monitored. In the case of this experimental stand, there was also added the parameter of inbuilt material humidity. This parameter, which substantially influences the thermal regime of the rail track structure and also the depth of subgrade freezing, is necessary for mathematical modelling of the subgrade thermal regime using the SoilVision software (closely characterized in [7]).

The experimental measurements of the thermal regime and variations in humidity in the rail track structure model and its subgrade at the experimental stand DRETM II have been carried out since 2013. That is why only two winter periods have been evaluated, winter of 2013/2014 and winter of 2014/2015. The required thermal characteristics of these two winter periods are determined in the same way, as with the experimental stand DRETM I. Tables 2 and 3 show the measurement results that were acquired in the case of no snow cover on the surface of the experimental stand during all the winter periods.

Equally as with the experimental stand DRETM I, the winter period, the above-mentioned parameters were stated for, is limited by the first and last frost period $\left(T_{s} \leq-0.1^{\circ} \mathrm{C}\right)$, while the frost period must last for at least four days and the winter period can consist of several frost periods. Their monitored characteristics are stated in Table 1.

Table 2: Parameters acquired by evaluating of the monitored quantities at the experimental stand DRETM II - 1st measuring profile without the protective layer.

\begin{tabular}{|c|c|c|c|c|c|c|}
\hline $\begin{array}{l}\text { Winter } \\
\text { period }\end{array}$ & $\begin{array}{c}\text { Temperature, } \\
\theta_{s, \max }\left({ }^{\circ} \mathrm{C}\right)\end{array}$ & $\begin{array}{l}\text { Temperature, } \\
\theta_{s, \min } \\
\left({ }^{\circ} \mathrm{C}\right)\end{array}$ & $\begin{array}{c}\text { Frost } \\
\text { index, } \\
I_{F} \\
\left({ }^{\circ} \mathrm{C} . \text { day }\right)\end{array}$ & $\begin{array}{l}\text { Surface } \\
\text { frost, } \\
\text { index } I_{F S} \\
\left({ }^{\circ} \mathrm{C} \text {.day }\right)\end{array}$ & $\begin{array}{c}\text { Depth of } \\
\text { freezing, } \\
D_{F} \\
(\mathrm{~m})\end{array}$ & $\begin{array}{c}I_{F} \text { for } D_{F, \max } \\
\left({ }^{\circ} \text { C.day) }\right.\end{array}$ \\
\hline $2013 / 2014$ & 10.45 & -11.70 & -38 & -22 & 0.43 & -32 \\
\hline $2014 / 2015$ & 8.50 & -10.80 & -77 & -32 & 0.42 & -75 \\
\hline
\end{tabular}

Table 3: Parameters acquired by evaluating of the monitored quantities at the experimental stand DRETM II - 2nd measuring profile with a protective layer.

\begin{tabular}{lllllll}
\hline Winter period & $\begin{array}{l}\text { Temperature, Temperature, } \\
\theta_{s, \max }\left({ }^{\circ} \mathrm{C}\right)\end{array}$ & $\begin{array}{l}\theta_{s, \min }\left({ }^{\circ} \mathrm{C}\right) \\
\text { index }, I_{F} \\
\left({ }^{\circ} \mathrm{C} . \text { day }\right)\end{array}$ & $\begin{array}{l}\text { Surface } \\
\text { frost } \\
\text { index, } I_{F S} \\
\left({ }^{\circ} \mathrm{C} \text {.day) }\right.\end{array}$ & $\begin{array}{l}\text { Depth of } \\
\text { freezing, } I_{F} \text { for }\end{array}$ & $\begin{array}{l}D_{F, \max } \\
\left({ }^{\circ} \mathrm{C} . \text { day }\right)\end{array}$ \\
\hline $2013 / 2014$ & 10.45 & -11.70 & -38 & -22 & 0.42 & -32 \\
$2014 / 2015$ & 8.50 & -10.80 & -77 & -32 & 0.41 & -75 \\
\hline
\end{tabular}


As manifested in Tables 2 and 3, the so far acquired measurement results at the experimental stand DRETM II from two latest winter periods confirm that not only the air frost index, $I_{F}$, influences the depth of subgrade freezing, $D_{F}$, but it is also influenced by the course and intensity of the frost period, the air frost index was based on reaching approximately the same depth of subgrade freezing, $D_{F}$, for double value of air frost index $I_{F}$. The comparison of individual set parameters for both monitored and evaluated winter periods is given in Figs. 4 and 5 show the course of daily mean air temperatures (at the ballast bed surface) and subsequently the frost indexes, $I_{F}$, (of the ballast bed surface $I_{F S}$ ) for winter periods of 2013/2014 and 2014/2015 are determined. Figures 7 and 8 show the course and the position of the zero isotherm in the subgrade for both winter periods.

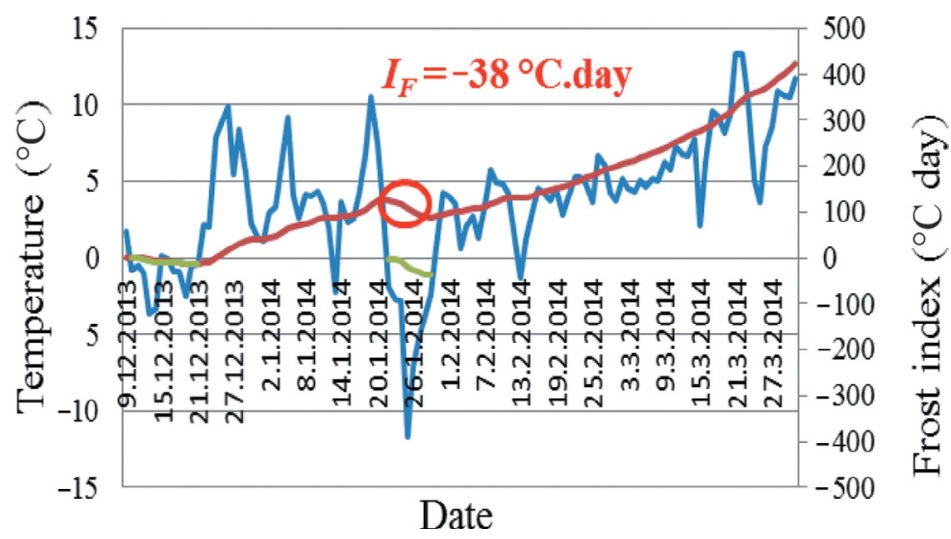

Figure 4: The stated value of the air frost index $I_{F}$ - winter 2013/2014.

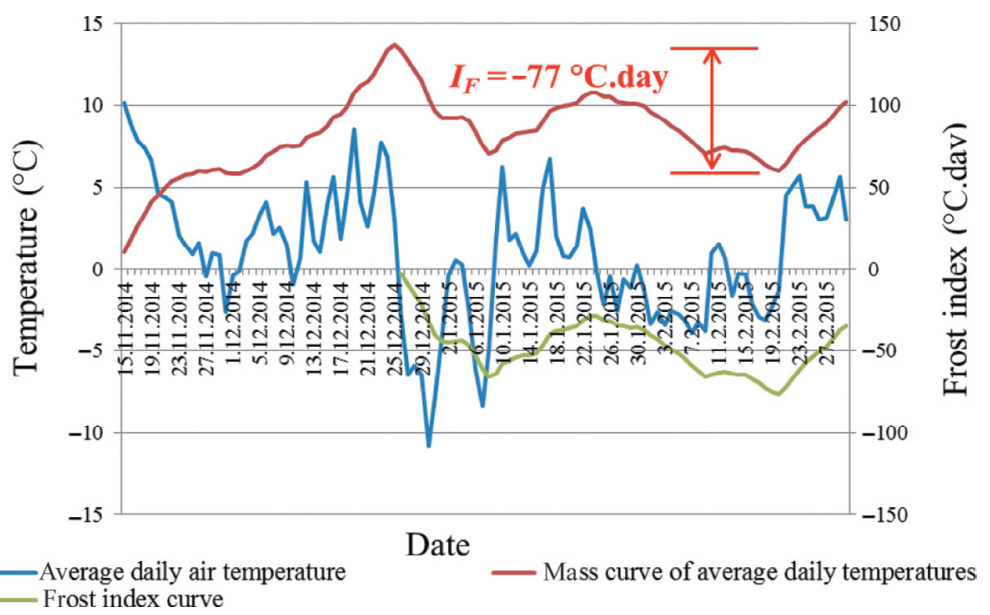

Figure 5: The stated value of the air frost index, $I_{F}$ - winter 2014/2015. 


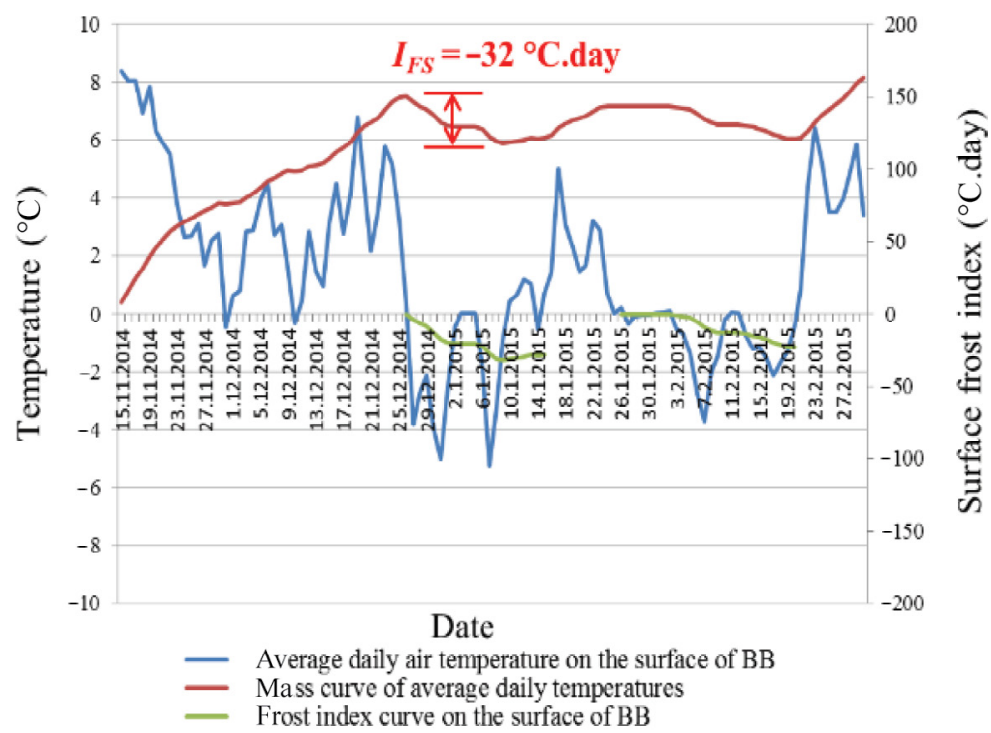

Figure 6: The stated value of the surface frost index, $I_{F S}$ - winter 2014/2015.

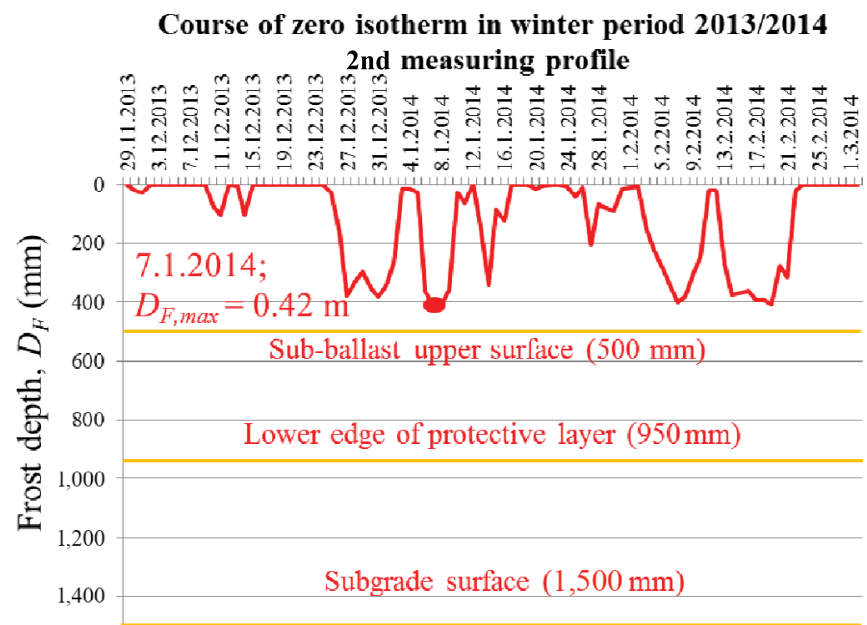

Figure 7: The stated value of the depth of subgrade freezing - winter period of 2013/2014.

Also the results of experimental measurements of two evaluated winter periods at the experimental stand DRETM II provide the same conclusions, as mentioned in relation to the DRETM I, that the depth of subgrade freezing is not only influenced by the frost index, $I_{F}$, but also by other factors, stated in the final section of the article. 


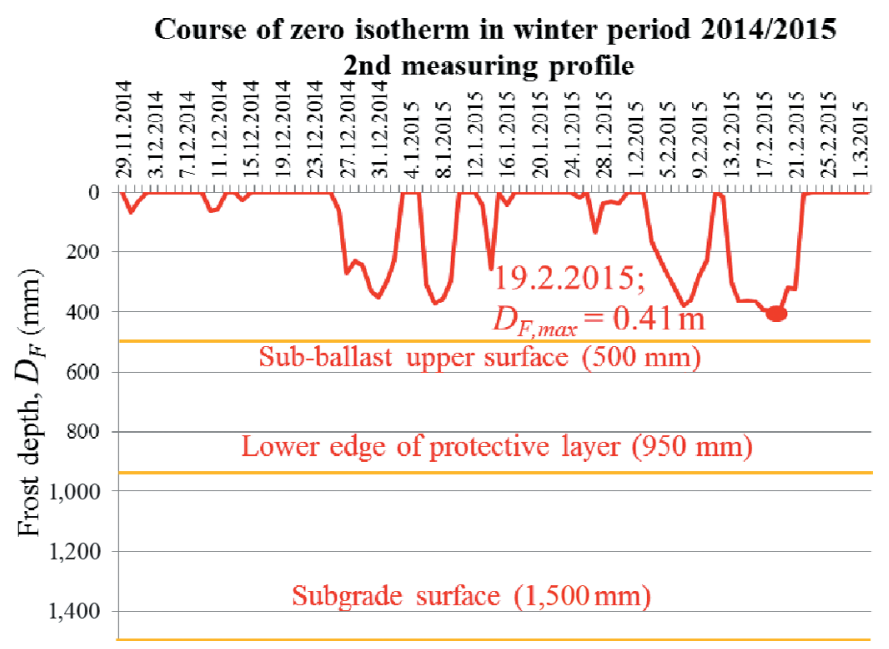

Figure 8: The stated value of the depth of subgrade freezing - winter period of 2014/2015.

\section{PRELIMINARY RESULTS FROM THE EXPERIMENTAL MONITORING OF THERMAL REGIME OF RAILWAY TRACK STRUCTURE}

The experimental measurements as well as the mathematical modelling of the thermal regime of the rail track (subgrade) confirmed that the air frost index is not the only parameter that influences the depth of rail track freezing. In the design methodology of the determination of structural thickness of the protective layer, it is also necessary to consider other characteristics, namely:

- length and number of frost periods,

- course of a dominant frost period during the winter,

- occurrence and thickness of snow cover,

- temperature of individual structural layers of railway track and its subbase in the beginning of the winter period, i.e. before the first frost period,

- humidity of materials of individual structural layers of the railway track, or the subbase in the case of a railway track run on an embankment, in the beginning of the winter period,

- average annual air temperature.

The measurement of the humidity of materials in the individual structural layers of rail track (subgrade) was justified and it is necessary to consider the determined range of actual measured humidity in the dimensioning methodology of subgrade structure for non-traffic load.

\section{ACKNOWLEDGEMENT}

The presented results and conclusions are the results of solving the VEGA 1/0275/16 Design optimization of sleeper subgrade due to non-traffic load aspect [9]. 


\section{REFERENCES}

[1] VEGA 1/0756/12, Experimental monitoring and mathematical modelling of thermal regime of railway subgrade structure. Scientific Research of Department of Railway Engineering, Faculty of Civil Engineering, University of Žilina, Žilina, available at http://svf.uniza.sk/ kzsth. VEGA - Ministry of Education, Science \& Research of the Slovak Republic, available at http://www.minedu.sk, Bratislava, SK, 2012-2015. Accessed 9 November 2015. Accessed: November 9, 2015.

[2] Ižvolt, L., Dobeš, P. \& Pitoňák, M., Some experience and preliminary conclusions from the experimental monitoring of the temperature regime of subgrade structure. Proceedings of the Computer in Railways XIV - Railway Engineering Design and Optimization, WIT Press, available at http://www.witpress.com, WIT Transactions on the Built Environment, 135, pp. 267-278, 2014. DOI: 10.2495/CR140211.

[3] TNŽ 73 6312, The design of structural layers of subgrade structures, GR ŽSR, Slovakia, 2005.

[4] S4 Railway substructure, Regulations of Slovak Railways ŽSR, 1999.

[5] Kupčuliak, P., Design and evaluation of railway subgrade structure of aspect of climatic load factors, Doctoral dissertation, Department of Railway Engineering and Track Management, Faculty of Civil Engineering, University of Žilina, 142 p., 2011.

[6] Dobeš, P., Optimization of the subgrade design for non-traffic load, Doctoral dissertation, Department of Railway Engineering and Track Management, Faculty of Civil Engineering, University of Žilina, available at http://svf.uniza.sk/kzsth, 136 p., 2015. Accessed: October 12, 2015.

[7] Hodas, S., Ižvol, L. \& Dobeš, P., Preliminary results and conclusions from mathematical modelling of thermal regime of railway track structure. Proceedings of the COMPRAIL 2016 - 15th International Conference on Railway Engineering Design \& Operation, Madrid, Spain, WESSEX Institute of Technology, available at http://www. wessex.ac.uk, WIT Press, available at http://www.witpress.com, Southampton, UK, 12p., 2016. Accessed: April 18, 2016.

[8] Trime Pico-profile Manual, available at http://www.imko.de/en/products/soilmoisture/ soil-moisture-sensors/trimepicoipht3. Accessed: December 1, 2015.

[9] VEGA 1/0275/16, Design optimization of sleeper subgrade due to non-traffic load aspect. Scientific Research of Department of Railway Engineering, Faculty of Civil Engineering, University of Žilina, Žilina, available at http://svf.uniza.sk/kzsth. VEGA - Ministry of Education, Science \& Research of the Slovak Republic, available at http:// www.minedu.sk, Bratislava, SK, 2016-2019. Accessed: February 23, 2016. 